\title{
Control Rights and Capital Structure: An Empirical Investigation*
}

\author{
Michael R. Roberts \\ The Wharton School, University of Pennsylvania \\ Amir Sufi \\ University of Chicago, Graduate School of Business
}

First Draft: January 8, 2007

Current Draft: January 31, 2007

\footnotetext{
*We thank Mark Leary, Mike Lemmon, and Mitchell Petersen for helpful comments. We thank Rahul Bhargava, Ali Khan, Wang Yexin, and Lin Zhu for excellent research assistance. Roberts gratefully acknowledges financial support from a Rodney L. White Grant and an NYSE Research Fellowship. Roberts: (215) 573-9780, mrrobert@,wharton.upenn.edu; Sufi: (773) 702-6148, amir.sufi@,chicagogsb.edu.
} 


\title{
Control Rights and Capital Structure: An Empirical Investigation
}

\begin{abstract}
:
We show that a large number of significant financing decisions of solvent firms are dictated by creditors, who use the transfer of control accompanying financial covenant violations to address the misalignment of incentives between managers and investors. After showing that financial covenant violations occur among almost one third of all publicly listed firms, we find that creditors use the threat of accelerating the loan to reduce net debt issuing activity by over $2 \%$ of assets per annum immediately following a covenant violation. Further, this decline is persistent in that net debt issuing activity fails to return to pre-violation levels even after two years, resulting in a gradual decline in leverage of almost 3\%. These findings represent the first, of which we are aware, piece of empirical evidence highlighting the role of control rights in shaping corporate financial policies outside of bankruptcy.
\end{abstract}


"[Ross] Johnson explained that he was looking for a structure in which he would retain significant control of his company...He remembered the backbreaking trips to GSW's bankers twenty years before and cringed. Banks...cramped his style."

-Barbarians at the Gate

"The Credit Facility also requires the company to meet certain financial ratios and tests. These covenants...significantly limit the operating and financial flexibility of the Company and limit its ability to respond to changes in its business..."

-Conmed Corp, 10-K filing, December 1998

In their survey of CFOs, Graham and Harvey (2001) report that the single most important consideration in setting debt policy is "financial flexibility," or the ability to finance projects out of internal funds. While subject to interpretation, there is good reason to believe that executives are actually referring to a desire to maintain control of their company - a desire that may be unfulfilled when earnings are earmarked for debt repayment and creditors use contractual rights to restrict managerial decision-making. In addition to the anecdotal evidence provided by the opening quotes, there is a rich theoretical literature on optimal contracting and security design in which creditors exert direct control over the financial policies of solvent firms (e.g., Aghion and Bolton (1992), Dewatripont and Tirole (1994), and Jensen and Meckling (1976)).

Despite the survey evidence and large theoretical literature, the empirical literature on capital structure has largely ignored the direct influence of creditors on the financing decisions of solvent firms. Instead, tradeoff (Scott (1976)) and pecking order (Myers and Majluf (1984)), as well as market timing (Baker and Wurgler (2002)), hypotheses view the capital structure decision as a portfolio problem facing managers, 
where creditor control rights are irrelevant as long as the firm meets its interest payments (Townsend (1979), Gale and Hellwig (1985), Hart (1995), Hart and Moore (1998)). While these views have had some success in explaining corporate financial policy, they have also encountered a number of critics suggesting that the capital structure puzzle is far from solved (Lemmon, Roberts, and Zender (2006)). ${ }^{1}$

In this paper, we provide novel evidence that creditors exert direct control over firms' financing decisions even outside of states of payment default. In doing so, we show that control right considerations are an important - and previously missing element of the capital structure debate. In particular, we show that a substantial fraction of financing decisions are dictated by creditors, who use financial covenant violations to exert control over the net debt issuance and leverage decisions of firms. In response to covenant violations, creditors significantly alter the financial policies of firms in a manner that is incongruent with the objectives of managers. While there is a significant body of literature examining the importance of covenants in debt contracts, we are the first, to our knowledge, to examine how the use of financial covenants fits into the broader capital structure debate. In particular, our results offer unique insight into how the misalignment of incentives between managers and investors leads to distinctly different financing decisions following a transfer of control.

Our analysis centers on a unique dataset containing information on the universe of credit agreements and financial covenant violations reported on firm's annual and

\footnotetext{
${ }^{1}$ Studies by Frank and Goyal (2003), Fama and French (2005), and Leary and Roberts (2006) all provide evidence suggesting that the pecking order fails to provide an accurate description of observed financing behavior. Studies by Alti (2006), Hovakimian (2006), Kayhan and Titman (2007), Leary and Roberts (2005), and Liu (2006) all provide evidence refuting the implications of market timing. Finally, survey evidence from Graham and Harvey (2001) show that tax and bankruptcy cost considerations rank fourth and seventh, respectively, in terms of their importance in the decision to use debt financing.
} 
quarterly SEC filings between 1996 and 2005. Using these data, we begin by documenting several interesting facts. First, $97 \%$ of credit agreements contain at least one financial covenant and almost $80 \%$ of these agreements explicitly restrict the amount of debt that a firm may have in their capital structure. Second, more than one quarter of all publicly listed firms in the US violate a financial covenant at some point during our sample horizon. Among firms with an average leverage ratio of at least $5 \%$, this fraction approaches one third. Thus, financial covenants are not only a prominent feature of debt contracts (Smith and Warner (1979) and Bradley and Roberts (2003)) but they are also frequently violated (Dichev and Skinner (2002)) and, importantly, rarely lead to default or acceleration of the loan (Gopalakrishnan and Parkash (1995)).

We then show that after firms violate a financial covenant, their net debt issuing activity declines sharply and permanently. Figure 1 reveals that net debt issuing activity, as a fraction of total assets, declines by $0.7 \%$ in the two quarters immediately after the violation. Further, this decline is persistent, lasting for over two years after the violation. The ultimate consequence of this decline in issuing activity is found in Figure 3, which shows a persistent decline in leverage ratios following the violation. Two years after the violation, leverage has declined by almost $3 \%$, a relative decline of $12 \%$ when compared to the average leverage ratio.

We then turn to a more formal analysis aimed at identifying within firm variation in net debt issuing activity associated with the covenant violation. Using a firm fixed effects specification, we find that net debt issuing activity declines by over $0.7 \%$ of assets in the quarter immediately following the covenant violation - a statistically and economically significant amount. Additionally, this result is robust to a number of 
controls, including parametric and semi-parametric controls for the variables on which financial covenants are often written. That is, we incorporate smooth and discontinuous functions of measures, such as the debt-to-ebitda ratio to account for the possibility that the ratio on which the covenant is written contains information about managers' preferences for issuing debt.

We also show that leverage rebalancing, or mean reversion in leverage ratios (e.g., Leary and Roberts (2005) and Flannery and Rangan (2005)), is not behind our findings. Firms with relatively high leverage ratios decrease their net debt issuing activity by an additional $1 \%$ of assets per quarter after violating a covenant - a $170 \%$ additional decrease in net debt issuances relative to that predicted by mean reversion alone. This result highlights the divergence between managerial and creditor objectives in financial policy, and it provides insight into the channel through which the transfer of control affects security issuance decisions.

To reinforce our identification strategy and support a causal interpretation of our results (i.e., covenant violations induce changes in financial policy that would not have otherwise occurred), we undertake a regression discontinuity design in order to control for the possible endogeneity of the covenant threshold and, consequently, the violation (Chava and Roberts (2006)). Using a sample of loans from the Dealscan database containing current ratio and net worth covenants, we are able to measure the precise distance from the covenant boundary for each firm-quarter observation. This information enables us to address any remaining endogeneity concerns by (1) incorporating into the regression specification smooth functions of the distance to the default threshold, and (2) focusing on the subsample of observations close to the covenant threshold, effectively 
homogenizing the violation and non-violation states. Our results reveal a nearly identical decline in net debt issuing activity following a covenant violation $(0.6 \%)$, thereby mitigating endogeneity concerns. Additionally, these findings mitigate sample selection concerns over self-reported covenant violations in SEC filings because the Dealscan sample contains all covenant violations - reported and unreported.

Finally, to gain even further insight into the precise mechanism by which creditors influence debt policy after a covenant violation, we examine a random sample of the SEC filings of violators to identify the specific actions that creditors take. Over $30 \%$ of the violators explicitly state that creditors reduce the credit facility amount in response to the covenant violation (Sufi (2007)), and 13\% report an increase in the interest spread as a result of the violation. These findings provide additional evidence supporting our main result: a large number of significant financing decisions are dictated by creditors who use the transfer of control accompanying covenant violations to address the incongruence between managerial and investor preferences.

While largely unexplored in the empirical capital structure literature, our use of covenant violations is related to recent work by Chava and Roberts (2006) and Nini, Smith, and Sufi (2006), who show that one implication of financial covenant violations is a reduction in investment activity. Our analysis here shows that financial policy is yet another margin on which creditors intervene in the operation of the firm following the transfer of control rights. In this sense, our findings are related to accounting studies examining the resolution of technical default (e.g., Beneish and Press (1993, 1995), Chen and Wei (1993), Sweeney (1994), and Dichev and Skinner (2002)) in that our results quantify a specific implication of the resolutions identified in these previous studies. 
Our paper is also related to studies examining the implications of agency problems for capital structure (e.g., Zwiebel (1996) and Berger, Ofek, and Yermack (1997)). ${ }^{2}$ Our findings compliment this literature by identifying a precise mechanism though which the misalignment of incentives impacts financing, namely, via the transfer of control rights accompanying covenant violations. Additionally, our study, in some sense, also takes a step back relative to these earlier works by identifying an ex post consequence of agency problems and control rights transfers - a necessary condition for these factors to impact ex ante decision making.

The remainder of the paper proceeds as follows. Section I describes our data, presenting summary statistics in the process. Section II lays the theoretical foundation and motivation for our study. Section III begins with a non-parametric analysis of the impact of covenants violations on financing, followed by a discussion of the identification problem, empirical strategy, and results. Section IV presents the results of our regression discontinuity design. Section $\mathrm{V}$ presents evidence from discussions in 10Q and 10-K SEC filings, and Section VI concludes.

\section{Data}

\section{A. Sample Construction}

We begin with all non-financial Compustat firm-quarter observations from 1996 through 2005. We choose 1996 as the start year for our sample construction to coincide with the imposition of the SEC's requirement that all firms submit their filings

\footnotetext{
${ }^{2}$ A number of studies document a negative association between leverage and growth opportunities (e.g., Bradley, Jarrell, and Kim (1984) and Frank and Goyal (2004)), often interpreted as evidence of debt overhang's impact on financing (Myers (1977)). For broad reviews of the capital structure literature, see Harris and Raviv (1991), Myers (2003), and Frank and Goyal (2005).
} 
electronically, a feature that we require to measure covenant violations. To ensure the continuity of our sample across all of our study, we condition on the presence of both period $t$ and $t-1$ data for all of the variables considered in our analysis. ${ }^{3}$ (All variables used in this study are formally defined in Appendix A.) To mitigate the impact of data errors and outliers on our analysis, we winsorize all variables at the $5^{\text {th }}$ and $95^{\text {th }}$ percentiles. Finally, because our primary analysis relies on within firm variation, we include only firms for which there are at least 4 consecutive quarters of available data. In concert, these criteria reduce the sample from 176,993 firm-quarter observations to 135,736 firm-quarter observations. ${ }^{4}$

We supplement the Compustat data with information on financial covenant violations collected directly from $10-\mathrm{K}$ and $10-\mathrm{Q}$ SEC filings. These data are available given SEC Regulation S-X, which requires that "any breach of a covenant of a[n] ... indenture or agreement which ... exist[s] at the date of the most recent balance sheet being filed and which has not been subsequently cured, shall be stated in the notes to the financial statements" (SEC (1988), as quoted by Beneish and Press (1993)). As Sufi (2007) notes, the SEC has reinforced this requirement in recent interpretations: "companies that are, or are reasonably likely to be, in breach of such covenants must disclose material information about that breach and analyze the impact on the company if material (SEC (2003))."

\footnotetext{
3 More precisely, we require for each firm-quarter observation nonmissing data for both the contemporaneous and lagged value for total assets, total sales, tangible assets, total debt, net worth, cash holdings, net working capital, EBITDA, cash flow, net income, interest expense, market to book ratio, book value of equity, and market value of equity.

${ }^{4}$ The largest drop in sample size is due to the fact that data on either current or lagged EBITDA (item 21) are missing for over 20,000 firm-quarter observations.
} 
In order to extract these data, we first match all Compustat quarterly observations to their respective $10-\mathrm{Q}$ or $10-\mathrm{K}$ filing. We then use a Perl program to search the filings for one of 20 terms. ${ }^{5}$ Each time the program finds a term, it prints the 10 lines before and after the term in a separate document. We manually check each passage to ensure that the existence of the term reflects a financial covenant violation. Thus, each firm-quarter observation in our sample either is or is not in violation of a covenant.

As Dichev and Skinner (2002) note, financial covenant violations that are reported by firms in their SEC filings likely represent situations in which they were unable to obtain an amendment or waiver to cure the violation by end of the reporting period. While this is in general correct, it is important to note that many of the violations reported in SEC filings are violations that are waived before the reporting period ends. In these cases, the firm voluntarily reports that it was in violation during the reporting period even though it has cured the violation by the end of the reporting period. Overall, the violations tracked in our data represent, on average, more serious violations than violations that could be cured before the end of the reporting period. We explicitly investigate the implications of this self-selection later in our analysis.

\section{B. Summary Statistics}

Although the SEC requires firms to report unresolved financial covenant violations, they do not require firms to detail exactly which covenant has been violated.

\footnotetext{
${ }^{5}$ The specific terms are: "in violation of covenant", "in violation of a covenant", "in default of covenant", "in default of a covenant", "in technical violation of covenant", "in technical violation of a covenant", "in violation of financial covenant", "in violation of a financial covenant", "in default of financial covenant", "in default of a financial covenant", "in technical violation of financial covenant", "in technical violation of a financial covenant", "in technical default of financial covenant", "in technical default of a financial covenant", "not in compliance", "out of compliance", "received waiver", "received a waiver", "obtained waiver", and "obtained a waiver."
} 
To give a sense of the types of financial covenants employed in private credit agreements, we present summary statistics in Table I for financial covenants contained in a sample of 3,603 private credit agreements entered into by 1,984 of the firms in our sample. $^{6}$ As Table I demonstrates, $97 \%$ of the credit agreements contain at least one financial covenant, which can be broadly categorized by the accounting measures on which they are based: debt to cash flow (58\%), debt to balance sheet items $(29 \%)$, coverage ratios $(74 \%)$, net worth (45\%), liquidity (15\%), and cash flow (13\%).

Table I also hints at the importance of financial covenants in the borrower's capital structure determination. Almost $80 \%$ of the credit agreements contain a financial covenant that restricts a ratio with debt in the numerator. In addition, most minimum coverage ratios contain interest payments in the denominator; these coverage ratio covenants therefore place an implicit limit on debt. Overall, almost $90 \%$ of the credit agreements contain either an explicit or implicit restriction on the borrower's total debt.

Panel A of Table II documents that $26 \%$ of firms in our sample experience a financial covenant violation at some point between 1996 and 2005. Among firms with an average leverage ratio of 0.05 or higher, the percentage of covenant violators increases to $30 \%$. Further, we remind the reader that these are lower bounds on the actual number of covenant violations because our sample conditions on reported violations. It also is important to emphasize that our sample consists of the universe of public firms, with only a few screens based on data availability. Thus, technical defaults occur for a substantial fraction of publicly-listed firms.

\footnotetext{
${ }^{6}$ For more details on these private credit agreements and how they were obtained, see Nini, Smith, and Sufi (2006). There are slightly fewer observations in Table I than in Nini, Smith, and Sufi (2006) given that some agreements detail financial covenants in an attached exhibit that is not included in the SEC filing.
} 
Panel A of Table II also presents the fraction of violators by industry, size, and whether the firm has an $\mathrm{S} \& \mathrm{P}$ corporate credit rating. Firms across all industries violate financial covenants with similar proportions, as do firms with and without a corporate credit rating. Smaller firms are much more likely to violate financial covenants than larger firms: firms with total assets less than $\$ 100$ million are almost 20 percentage points more likely to violate a financial covenant than firms with total assets over $\$ 5$ billion.

Panel B of Table II presents the one year probabilities of violating a financial covenant in our sample based on the S\&P corporate credit rating. Firms rated A or better have a one year probability of violating a covenant of only $1 \%$, while firms rated BB have a $7 \%$ probability. Relative to the one year payment default probabilities reported by $\mathrm{S} \& \mathrm{P}$, the probabilities of a covenant violation are larger in every rating category except firms rated $\mathrm{CCC}$ or worse. The difference in the probabilities is particularly large for firms rated $\mathrm{BB}$ or better. Thus, even firms that are very unlikely to default on payments face a non-trivial probability of violating a financial covenant.

Table III presents the summary statistics for our outcome variables (net debt issuances and book leverage), our "covenant control variables," and "other control variables." The second group contains many of the accounting ratios on which financial covenants are written. As such, they provide a means to control for variation in accounting variables that are correlated with both the event of a violation and the propensity to issue debt. The third group contains additional control variables suggested by the empirical capital structure literature (e.g., Frank and Goyal (2005)) as being relevant for financial policy. In sum, the means and medians, once annualized, coincide with those found in previous studies. 


\section{The Consequences of Covenant Violations: Practice and Theory}

\section{A. Financial Covenants and Creditor's Rights}

Before discussing the theoretical motivation for why covenant violations might impact firms' financial policies, it is useful to first clarify precisely what financial covenants require and what happens when they are violated. To do so, we use the revolving credit agreement between Digitas Inc. and Fleet National Bank, originated on July 25, 2000, as an illustrative tool. Section 11 of the agreement details the financial covenants, a small excerpt of which is presented below.

\section{FINANCIAL COVENANTS OF THE BORROWER.}

The Borrower covenants and agrees that ...:

11.1. Leverage Ratio. The Borrower will not, as of the last day of any fiscal quarter, permit the Leverage Ratio for such fiscal quarter to exceed 2.50:1.00.

11.2. Minimum EBITDA. The Borrower will not, as of the end of any Reference Period, permit the consolidated EBITDA of the Borrower and its Subsidiaries for such Reference Period to be less than $\$ 20,000,000$.

If a borrower fails to comply with any of the financial covenants, then the borrower is in "technical default" of the agreement. Provisions in the credit agreement grant creditors the right to immediately accelerate outstanding amounts in response to technical defaults. In addition, technical defaults give creditors the right to terminate any unused portion of lines of credit or revolving credit facilities. In the Digitas credit agreement, these rights are outlined in Section 14.1 of the agreement and, more generally, are fairly common across most credit agreements.

14.1. Events of Default and Acceleration. If any of the following events ... shall occur:

(c) the Borrower shall fail to comply with any of its covenants contained in [the section describing financial covenants];... Then ... [Fleet] may ... 
by notice in writing to the Borrower declare all amounts owing with respect to this Credit Agreement, the Revolving Credit Notes and the other Loan Documents and all Reimbursement Obligations to be, and they shall thereupon forthwith become, immediately due and payable without presentment, demand, protest or other notice of any kind ...

14.2. Termination of Commitments. If any one or more of the Events of Default ... shall occur, any unused portion of the credit hereunder shall forthwith terminate and each of the Banks shall be relieved of all further obligations to make Revolving Credit Loans to the Borrower and the Agent shall be relieved of all further obligations to issue, extend or renew Letters of Credit.

While private credit agreements give creditors the right to accelerate outstanding balances in response to technical defaults, extant research suggests that most technical defaults lead to renegotiation and waivers as opposed to acceleration (Gopalakrishnan and Parkash (1995), Chen and Wei (1993), Beneish and Press (1993)). ${ }^{7}$ However, extant research also finds that creditors use their acceleration right to extract amendment fees, reduce unused credit availability, increase interest rates, and restrict corporate investment (Gopalakrishnan and Parkash (1995), Chen and Wei (1993), Sufi (2007), Chava and Roberts (2006), Nini, Smith, and Sufi (2006)). Thus, covenant violations appear to have a number of implications, but these implications are generally far removed from bankruptcy.

\section{B. Theory and Hypothesis Development}

Theoretical research in security design and optimal financial contracting makes assumptions about the structure of the information and the contracting environment, and shows that debt securities may be optimal in the presence of agency conflicts and/or

\footnotetext{
${ }^{7}$ Thus, extant research suggests that private credit agreements give creditors the ability to force borrowers into ex post renegotiation after covenant violations, where the contract provides the creditor with significant bargaining power. This feature of private credit agreements is broadly consistent with hypotheses developed in the incomplete contracts literature (Hart and Moore (1988)).
} 
contractual incompleteness. Townsend (1979) and Gale and Hellwig (1985) are among the earliest contributions. In their models, borrowers witness a state variable correlated with profitability that is unobservable to creditors. The optimal contract in this environment specifies a fixed payment in the unmonitored states; if a fixed payment is missed, creditors choose to "observe" the state and borrowers repay as much as possible. The authors interpret this contract as a standard debt contract in which creditors receive residual firm value when an interest payment is missed. Hart (1995) and Hart and Moore (1998) use an incomplete contracts framework in which cash flows are non-verifiable, managers can divert project returns, and creditors have the ability to seize physical assets. Under some additional assumptions, they too show that standard debt contracts that allow seizure of assets conditional on non-payment are optimal.

These models share the hypothesis that debt contracts allocate creditors residual control rights of physical assets in response to a payment default. As long as the firm meets its payment obligations, creditors play a passive role in firm financial and investment policy. The latter hypothesis is reflected in the three theoretical frameworks that have most strongly influenced empirical capital structure research: the trade-off, pecking order, and market timing frameworks. While the hypotheses of these three frameworks are generally distinct, they all treat the capital structure decision as a portfolio problem facing managers, as alluded to at the outset of the paper. Thus, in these theories, creditors do not have any direct control over the capital structure decisions of firms, unless the firm defaults on a payment obligation.

There is an alternative class of models in which creditors play a more active role in firm financial and investment policy, even if the borrower meets its payment 
obligations. Jensen and Meckling (1976) assume the existence of debt and equity securities and analyze how risk-shifting tendencies of managers acting on behalf of shareholders influence debt contracts. Given incentive conflicts introduced by managers' convex payoff functions, creditors will attempt to mitigate risk-shifting through covenants restricting firm investment and financial policy even before firms have defaulted on payment obligations.

Aghion and Bolton (1992) use an incomplete contracting framework in which a wealth-constrained owner-manager seeks capital to finance projects that produce both cash profits and managerial private benefits. In their model, origination contracts allocate control rights to creditors in future states where managerial private benefits are most likely to distort the manager into inefficient decisions. Importantly, control rights may shift to creditors even in the absence of a payment default. Indeed, as they emphasize in their conclusion, the manager continues to receive monetary payoffs even after creditors "take control" of the firm. ${ }^{8}$

Dewatripont and Tirole (1994) assume the existence of an ex ante managerial moral hazard problem, and they find that optimal financial contracts with concave cashflow rights encourage debt-holders to acquire control rights after signs of poor performance. Loss of control serves as a managerial disciplining device, and therefore helps mitigate moral hazard. In their model, a noisy signal correlated with firm performance is contractible, and control shifts to creditors conditional on negative realizations of the signal. Importantly, a negative realization of the signal does not

\footnotetext{
${ }^{8}$ Hart (1995) has criticized this aspect of the Aghion and Bolton (1992) model: "One of the most basic features of a debt contract is the idea that what triggers a shift in control is the non-payment of a debt ... the Aghion-Bolton contract does not have this property (p 101)."
} 
necessarily entail payment default; therefore, creditors may obtain a degree of control over firm policy outside of states of bankruptcy.

While these three models assume different types of incentive conflicts, they reach a similar conclusion: in the presence of agency conflicts, optimal financial contracts may allocate a certain degree of control over firm policy to creditors even before a payment default. Extant research shows that creditors exert control over firm capital expenditure policy after negative performance but before payment default (Chava and Roberts (2006) and Nini, Smith, and Sufi (2006)). However, to our knowledge, there is no existing empirical research in the capital structure literature that documents creditors' direct influence on the security issuance decisions of solvent public firms.

The null hypothesis that we take to our empirical analysis is that creditors play a passive role in firms' capital structure decisions before payment default. This is consistent with the theories of Townsend (1979), Gale and Hellwig (1985), Hart (1995), and Hart and Moore (1998). It is also consistent with current empirical capital structure research based on trade-off, pecking order, and market timing frameworks. The alternative hypothesis is that creditors play a more direct role in the security issuance decisions of firms before payment default. In the context of financial covenant violations, the alternative hypothesis is that creditors use their acceleration right to directly influence the capital structure decisions of borrowers subsequent to technical defaults. Evidence in favor of the alternative hypothesis would suggest that a consideration of creditor control rights outside of payment default states is an important—and previously missing — part of the capital structure debate. 


\section{The Effect of Covenant Violations on Capital Structure}

\section{A. Security Issuances and Covenant Violations}

In this section, we examine whether creditors use their acceleration rights after financial covenant violations to influence capital structure decisions of the firm. We begin with a simple within-firm analysis to identify the effect of the covenant violation on financial policy and corporate leverage. Specifically, we estimate the following specification for the outcome variable $y$ :

$$
y_{i t}=\alpha_{i}+\sum_{f=1}^{4} \theta_{f}+\sum_{t=1996 q 3}^{2005 q 2} \delta_{t}+\sum_{j=-2}^{8} \beta_{j} I\left(\text { Violation }_{i t+j}\right)+\eta_{i t}
$$

where $i$ indexes firms, $t$ indexes quarters, $\alpha_{i}$ correspond to firm fixed effects, $\theta_{f}$ correspond to fiscal quarter fixed effects, $\delta_{t}$ correspond to calendar year-quarter fixed effects, I(Violation $\left.{ }_{i t+j}\right)$ is a set of indicator variables surrounding the quarter in which a covenant violation occurred $(j=0)$, and $\eta_{i t}$ is a random disturbance assumed to be possibly heteroskedastic and correlated within firms (Petersen (2006)). The $\beta_{j}$ correspond to the deviation of $y$ from the firm-specific average for the quarters around the time of the covenant violation. $^{9}$

Figures 1 through 3 present graphical representations of $\beta_{-2}$ through $\beta_{8}$, along with corresponding $90 \%$ confidence intervals, for $y$ equal to net debt issuances, net equity issuances, and book leverage, respectively. Beginning with Figure 1, we observe that for the three quarters up to and including the quarter of the violation, firms experience no significant change in net debt issuance, and there is no discernable trend. Indeed, these estimates are only slightly above the firm-specific mean but insignificantly so.

\footnotetext{
${ }^{9}$ The estimation presented in Figures 1 through 3 restricts attention to firms that are in the sample for the eight quarters after the covenant violation to avoid any bias from firm exit. Estimates relaxing this restriction are qualitatively similar and are reported in Table VII.
} 
Immediately following the violation, firms experiences a sharp decrease in net debt issuance. By the second quarter after the covenant violation, net debt issuance activity has fallen by $0.7 \%$ of assets relative to the issuance activity in the quarter of the violation. This decline is not only statistically significant at all conventional levels it is also economically large, corresponding to an annualized decline in the net flow of debt equal to almost 3\%. Additionally, this change in net debt issuance policy shows persistence. Even two years later, net debt issuances are significantly lower than they were in the three quarters up to and including the quarter of the covenant violation.

Figure 2 presents the results for net equity issuances. Unlike net debt issuances results, there is no sharp change in net equity issuances right after the covenant violation. There is some evidence of an increasing trend following the violation; however, it is statistically weak and economically small.

Figure 3 shows that the sharp and persistence reduction in net debt issuances revealed by Figure 1 has a significant effect on leverage ratios. By the fourth quarter after the covenant violation, firm leverage is statistically significantly lower than that in the quarter before the covenant violation. By the sixth quarter after the violation, firm leverage is not statistically distinct from the average leverage of the firm outside the covenant violation window. In other words, in six quarters, the firm reduces its leverage from almost 300 basis points above the firm mean back to the firm mean. The mean leverage ratio of firms that violate a covenant at some point during our sample horizon is 0.27 , which implies a relative reduction in leverage of over $10 \%$ following the covenant violation. 


\section{B. Identification}

As discussed in Section III, the alternative hypothesis for our empirical analysis is that creditors use their acceleration rights to directly influence capital structure subsequent to a covenant violation. The evidence in Figures 1 through 3 is consistent with the alternative hypothesis: it suggests that creditors use their acceleration right to impose a sharp change in net debt issuances immediately after the violation. However, the evidence does not necessarily reject the null hypothesis that management makes capital structure decisions independent of direct creditor influence. The primary concern is that financial covenants are written on financial variables that may be correlated with management's optimal capital structure policy even in the absence of the covenants themselves. For example, the classic tax-bankruptcy cost trade-off theory suggests that when leverage rises, expected costs of bankruptcy rise, and, consequently, firms should decrease their leverage. Thus, the basic concern is that the decline in net debt issuances and leverage would have occurred even if there had been no covenant violation because managers would have rebalanced their capital structures (e.g., Leary and Roberts (2005)), for example.

That said, several features of Figures 1 and 3, in particular, suggest that our findings may be more than simply coincidental. Figure 3 shows that leverage ratios are well above the firm mean even before the covenant violation, but Figure 1 shows that the decrease in net debt issuance begins only after the firm violates a financial covenant. Figure 3 also suggests that firms push their leverage ratios after the violation well below the leverage ratio measured before the covenant violation. These two facts suggest that firms are already above their optimal leverage ratio before the covenant violation, but 
they only reduce net debt issuance after violating a covenant. Finally, Figure 1 shows that the major change in net debt issuance policy is concentrated exactly in the quarter after the covenant violation. The evidence in Figures 1 through 3, together with evidence from credit agreements describing creditors' acceleration rights, suggest that management would not have decreased net debt issuance as sharply had they not violated the covenant.

Nonetheless, the next two subsections take additional steps toward ensuring a causal interpretation of our results.

\section{Covenant control variables}

The first identification concern is that the variables on which covenants are written (e.g., debt-to-ebitda) contain information about managerial preferences for net security issuing activity. If so, then any change in security issuance policy following a covenant violation may simply reflect a corresponding change in managerial preferences. To address this concern, we incorporate smooth and discontinuous functions of variables on which covenants are typically written. The identifying assumption is that by conditioning on parametric and non-parametric covenant control variables, we are able to isolate variation in covenant violations that is independent of the underlying variables that management may use to adjust capital structure in the absence of the covenant violation. This assumption is valid as long as managers, in the absence of financial covenants, would not have chosen the exact same ratios and levels of the ratios, as creditors to determine net debt issuance policy.

For the empirical analysis of the full sample, we construct a matrix of right-handside variables, $X$, consisting of 16 variables on which covenants are written. The matrix 
includes 12 non-interaction (i.e., level) covenant controls: the lagged book debt to assets ratio, the lagged net worth to assets ratio, the lagged cash to assets ratio, the lagged and current EBITDA to lagged assets ratio, the lagged and current cash flow to lagged assets ratio, the lagged and current net income to lagged asset ratio, and the lagged and current interest expense to lagged assets ratio. We also allow for four interaction terms: the lagged debt to assets ratio interacted with the lagged cash flow to lagged assets ratio, the lagged debt to assets ratio interacted with the lagged EBITDA to lagged assets ratio, the lagged debt to assets ratio interacted with the lagged net worth to assets ratio, and the lagged EBITDA to lagged assets ratio interacted with the lagged interest expense to lagged assets ratio.

The choice of these controls is based on the most common financial covenants employed in private credit agreements (Table I), as well as collinearity considerations. Many of the accounting ratios behind financial covenants are highly correlated (e.g., debt to cash flow versus senior debt to cash flow, fixed charge coverage ratio versus interest coverage ratio, etc.). Thus, near-singularity concerns preclude an all-inclusive set of covenant controls.

Following the extant empirical capital structure literature (e.g., Rajan and Zingales (1995)), the matrix $X$ also includes the natural logarithm of assets, the lagged tangible to total assets ratio, and the lagged market to book ratio. Given this matrix $X$, we estimate the following firm fixed effects specification,

$\frac{D_{i, t}-D_{i, t-1}}{A_{i, t-1}}=\alpha_{i}+\sum_{f=1}^{4} \theta_{f}+\sum_{t=199693}^{2005 q 2} \delta_{t}+\beta_{0} *$ Violation $_{i, t}+\beta_{1} * \operatorname{Violation}_{i, t-1}+\Gamma * f\left(X_{i, t-1}, X_{i, t}\right)+\eta_{i t},(2)$ 
where $f(X)$ corresponds to a vector a parametric and non-parametric controls for the variables on which covenants are written, and all other variables are defined above in the context of equation (1).

Column (1) of Table IV presents the estimation results from the baseline firm fixed effects specification with only fiscal quarter and quarter indicator variables as controls (i.e., restricting $\Gamma=0$ ). The results show that net debt issuance falls from 8 basis points above the firm mean to 62 basis points below in the quarter immediately after the covenant violation, a decline of 70 basis points. The point estimate is statistically distinct from zero at less than the one percent level, with a $t$-statistic of eight, even after removing firm fixed effects and accounting for within firm correlation (Petersen (2006)). The specification reported in Column (2) adds linear controls for the 12 non-interaction covenant control variables mentioned above. The magnitude of the coefficient declines slightly but remains statistically distinct from zero at the one percent level. In Column (3), we add the four interaction terms mentioned above, which have little impact on the estimated covenant violation coefficient.

Finally, column (4), presents the results for a kitchen sink specification including the following controls: the 16 covenant control variables (level and interaction terms), higher order polynomial terms (squared and cubic terms) for each of the 16 covenant controls, and quintile indicator variables for each of the 16 covenant controls. To be clear, the last set of controls consists of $80(5 \times 16)$ indicator variables, where each indicator variable equals one if the year-quarter observation for a firm falls in the relevant quintile of the covenant control distribution. The Adjusted $\mathrm{R}^{2}$ of the regression increases by more than 3 times that of the regression reported in column (1), suggesting that these 
additional controls have significant predictive power. However, even with this extensive set of over 120 covenant control variables, the covenant violation coefficient estimate is unaffected, remaining at -51 basis points with a $t$-statistic of 7.4.

The results in Table IV suggest that the covenant violation is uniquely associated with a drop in net debt issuance, even after controlling for the variables on which covenants are written both parametrically and non-parametrically. Given our identification assumption, these results suggest that net debt issues decrease by 51 basis points more than they would have in the absence of the covenant violation. In terms of magnitudes, a quarterly reduction in net debt issuance of 51 basis points takes a firm from the median of the net debt issuance distribution to the $28^{\text {th }}$ percentile.

\section{Managerial Rebalancing of Leverage Ratios}

The next identification concern is managerial rebalancing. Previous research suggests that managers dynamically rebalance their leverage ratios (e.g., Leary and Roberts (2005) and Flannery and Rangan (2006)) and many managers explicitly report having a target range for the debt to equity ratio (Graham and Harvey (2001)). This behavior is a threat to our identification strategy if the covenant violations simply coincide with leverage ratios that are, in some sense, too high. That is, absent the covenant violation, a reduction in net debt issuing activity would have occurred in the process of firms' rebalancing their leverage ratios. In fact, the results in Table IV already address this concern by showing that the magnitude of the effect of covenant violations on net debt issuance is robust to both parametric and non-parametric controls for the lagged book leverage ratio. 
Nonetheless, in this subsection, we examine the managerial rebalancing hypothesis further. Specifically, we examine the change in net debt issuances for covenant violators versus non-violators across the leverage distribution. Panel A of Table $\mathrm{V}$ splits the sample into quartiles based on the change in leverage ratio from $t-2$ to $t-1$, and examines net debt issuance at time $t$ by whether the firm violates a financial covenant. Quartile 1 (4) corresponds to firms experiencing a small (large) change in leverage. In all quartiles, average net debt issuance is significantly lower for covenant violators versus non-violators. In fact, covenant violators in the lowest quartile of the lagged change in leverage ratio distribution experience sharper declines in net debt issuance than non-violators in the highest quartile, a difference that is statistically distinct from zero at the one percent level.

Panel B splits the sample based on the level of leverage ratio in period $t-1$. The first column shows a rebalancing effect among non-violators, albeit a non-monotonic effect. Firms in higher lagged leverage quartiles have smaller increases in net debt issuance, which is consistent with evidence in Leary and Roberts (2005). As in Panel A, net debt issuance of covenant violators is lower in every quartile of the distribution of lagged leverage ratios. In fact, covenant violators in the second quartile have net debt issuance that is lower than non-violators in the highest leverage quartile, a difference that is statistically distinct from zero at the five percent level. If managerial rebalancing were the only effect, then it is unlikely that violators in lower leverage quartiles would be reducing net debt issuance by more than non-violators in higher leverage quartiles. The evidence in Panel B shows that all firms tend to rebalance when leverage ratios increase; 
however, the covenant violators reduce net debt issuance by more and at lower lagged leverage ratios.

Table VI examines the rebalancing alternative in a regression context. The specifications reported in columns (1) and (2) of Table VI are identical to the specification reported in column (3) of Table IV (see equation (2) above), but for the addition of three indicator variables for the change in lagged leverage quartiles (column (1)) and lagged leverage ratio quartiles (column (2)) plus four interaction terms of the quartile indicator variables and the lagged covenant violation. The coefficient estimates on the lagged quartile indicators represent the within-firm baseline rebalancing effect, and the coefficient estimates on the interactions represent how much larger the rebalancing effect is when a firm violates a financial covenant.

Consistent with managerial rebalancing, the estimates in column (2) imply that firms that enter into the $3^{\text {rd }}$ and $4^{\text {th }}$ quartile of the leverage distribution reduce net debt issuance by 35 basis points and 63 basis points, respectively. This finding coincides with the mean reversion found in previous empirical capital structure studies. When we consider the effect of a covenant violation, net debt issuance declines by an additional 52 and 110 basis points for these two quartiles, respectively. While firms that enter into the second quartile of the leverage distribution do not reduce net debt issuance by a statistically significant amount, covenant violators reduce net debt issuance by a statistically significant 37 basis points. Thus, covenant violators reduce net debt issuance by significantly more than non-violators across most of the leverage distribution, above and beyond any reduction coinciding with normal rebalancing motives. 
These findings have a useful interpretation in that they highlight the wedge between the firm's optimal capital structure and the creditor's optimal capital structure. For the second, third, and fourth quartiles of lagged leverage, the estimates in Table VI imply that covenant violators reduce net debt issuance by twice as much as would be predicted from managerial rebalancing alone. This is consistent with creditor's taking a more conservative approach to debt usage than firms.

\section{E. Short-Run vs. Long-Run Impact}

In Tables IV through VI, we examine the impact of covenant violations in the quarter immediately after the covenant violation in order to isolate the causal effect of creditor control rights on financing decisions. In Table VII, we examine the long run impact of the covenant violation on net debt issuances and leverage ratios. The regression specifications in columns (1) through (4) of Table VII are identical to the specifications reported in columns (1) through (4) of Table IV, respectively, but for the inclusion of covenant violations indicators for two quarters before the covenant violations and eight quarters after. The sample for the specification is smaller given the necessity of having violation data for all quarters.

Column (1) presents the long run estimation results from the baseline firm fixed effects specification with only fiscal quarter and quarter indicator variables as controls. Net debt issuance for the firm drops sharply in the two quarters after the covenant violation, and remains statistically significantly lower than the firm mean even eight quarters after the violation. Columns (2) through (4) include the comprehensive set of control variables described in Table IV; the short run and long run effects are 
qualitatively similar, with only slightly smaller magnitudes. The estimates presented in columns (1) through (4) indicate a sharp and persistent decline in net debt issuing activity, even after the rigorous set of controls for variables on which covenants are written.

The results reported in columns (5) and (6) demonstrate the long run effect of the sharp and persistent decline in net debt issuances on leverage ratios. Column (5) presents estimates from a specification including only fiscal quarter and quarter indicator variables as controls, and shows that leverage ratios gradually decline in response to the covenant violation. By 4 quarters after the violation, the leverage ratio is lower than the leverage ratio in the quarter before the violation, a difference that is statistically distinct from zero at the five percent level. By 6 quarters after the violation, the leverage ratio is not statistically distinct from the long run firm average at a meaningful confidence level. The coefficient estimates reported in column (6) are from a specification which includes standard controls used in the capital structure literature (lagged natural logarithm of assets, lagged asset tangibility, lagged market to book, and the current and lagged EBITDA, cash flow, and net income scaled by lagged assets). The results are almost identical.

\section{Regression Discontinuity Design}

While we have attempted to control for all confounding effects in the preceding analysis, a remaining concern is that the covenant threshold or the distance to that threshold contains information about managers' preferences for debt financing. An additional concern is that the self-reporting of covenant violations in SEC filings may 
bias our results in favor of finding a (large) effect because only "severe" violations are reported. To address these concerns, we turn our attention to a different dataset that does not rely on self-reporting of covenant violations and contains sufficient information to construct measures of the covenant threshold and the corresponding distance to that threshold. Doing so enables us to employ a regression discontinuity design (e.g., Hahn, Todd, and Van der Klaauw (2001) aimed at reinforcing a causal interpretation of our results and ensuring that our findings are not driven by sample selection.

Both the data and empirical strategy of this section are similar to that found in Chava and Roberts (2006). To avoid any unnecessary redundancy and manage the length of our study, we purposely keep the discussion of the data and methodology brief in order to focus our attention on the results. However, where relevant, we refer to the reader to their study for further details.

\section{A. Data}

The data used in this section of the paper begins with a sample of loans from the Dealscan database that we are able to successfully merge with the quarterly Compustat database by linking company names and loan inception dates. This merge generates a sample of 37,764 loans, or tranches, grouped together into 27,022 deals and corresponding to 6,716 firms. Because covenants generally apply to all loans in a deal, we focus our attention on the deal level. Further, we restrict the sample horizon to loans with start dates between 1994 and 2005, and containing a covenant restricting either the current ratio or net worth/tangible net worth to lie above a certain threshold. 
The motivations for this sample selection are as follows. First, significant covenant coverage in the Dealscan database begins only in 1994. Second, current ratio and net worth covenants appear relatively frequently in the Dealscan database, contained in 6,386 deals with a combined face value of over one trillion dollars. Second, as Dichev and Skinner (2002) note, the accounting measures used for these two covenants are standardized and unambiguous. This is in contrast to other covenants that restrict, for example, the ratio of debt to EBITDA. Depending on the specific loan, "debt" may refer to long term debt, short term debt, total debt, funded debt, secured debt, etc. Covenants relying on measures of leverage or interest payments face similar difficulties, which is consistent with the evidence provided by Leftwich (1983) who suggests that one way in which private lenders customize their contracts is through adjustments to GAAP when defining financial statement variables.

Our final analysis sample is a panel of firm-quarter observations in which each observation either is or is not in violation of a covenant. To determine whether a firm is or is not in violation, we compare the firm's actual accounting measure to the covenant threshold implied by the terms of the contract. As Chava and Roberts (2006) describe, the measurement of the threshold is non-trivial since covenants often change over time, firms enter into overlapping loan agreements, and firms can amend their loans after inception. All of these issues are explicitly addressed in their study and, as such, we simply follow their construction.

Before outlining our empirical framework, it is useful to briefly describe the distinction between this dataset constructed from Dealscan and the previous one constructed from the SEC filings. The clearest distinction stems from the fact that not all 
violations must be reported. Technically, only violations that remain unresolved at the time of reporting must be documented in SEC filings. Extant research documents that a number of violations are waived (Chen and Wei (1993)) or lead to renegotiations in which the terms of the contract are modified to alleviate the breached covenant(s).

Another distinction comes from the fact that only credit agreements in excess of $10 \%$ of assets are required to be filed with the SEC. According to Loan Pricing Corporation, the distributors of Dealscan, approximately $60 \%$ of their loans come from SEC filings, while the rest are obtained from contacts in the credit industry - an increasingly important source over time.

That said, an important by-product of this analysis is that it offers a test of any sample selection bias associated with the filings data. Because only reported violations are captured by the SEC filings, one concern with our previous results is that they reflect only the most egregious violations, suggesting an overstatement of the actual impact of control changes. Alternatively, the sample selection associated with the filings data may be representative of an underlying economic distress associated with the covenant violation. Again, the selection bias leads to an overstatement of the estimated impact of covenant violations.

\section{B. Empirical Strategy}

Hahn, Todd, and Van der Klaauw (2001) note that, "the regression discontinuity data design is a quasi-experimental data design with the defining characteristic that the probability of receiving treatment changes discontinuously as a function of one or more underlying variables." (page 1) In the current context, covenant violations correspond to 
the treatment and non-violations the control. What enables our research design to fit into the regression discontinuity paradigm is that the function mapping the distance between the underlying accounting variable and the covenant threshold into the treatment effect is discontinuous. Specifically, our treatment variable, Bind, is defined as:

$$
\text { Bind }_{i t}=\left\{\begin{array}{l}
1 \text { if } z_{i t}-z_{i t}^{0}<0 \\
0 \text { otherwise }
\end{array}\right.
$$

where $z$ is the observed current ratio (or net worth), $z^{0}$ is the covenant threshold, and $i$ and $t$ index firms and quarters, respectively.

Our base empirical model for this section is similar to that in the previous section:

$$
\frac{D_{i t}-D_{i t-1}}{A_{i t-1}}=\alpha_{i}+\sum_{f=11}^{4} \theta_{f}+\sum_{1994 q 1}^{2004 q 1} \delta_{t}+\beta_{0} \text { Bind }_{i t-1}+\beta_{1}{ }^{\prime} X_{i t-1}+\eta_{i t},
$$

where all variables are as defined before. The parameter of interest is $\beta_{0}$, which represents the impact of a covenant violation on firm $i$ 's net debt issuing activity. The appeal of this approach is that the nonlinear relation in equation (4) provides for identification of the treatment effect under very mild conditions (Hahn, Todd, and Van der Klaauw (2001)). Indeed, in order for the treatment effect, $\beta_{0}$, to not be identified, it must be the case that the unobserved component of net debt issuances, $\varepsilon$, exhibits an identical discontinuity as that defined in equation (3) - relating the violation status to the underlying accounting variable. Because we can now measure the distance from the threshold, we can include smooth functions of this distance into the set of control variables $X$. Doing so alleviates the endogeneity concern because the identification of the treatment effect is driven 
entirely by the discontinuity at the threshold and not from the distance to the threshold, which is now a control variable.

\section{Results}

The estimation results are presented in Panel A of Table VIII. The first specification presents the response of net debt issuances to the covenant violation conditional only on firm and period fixed effects. Interestingly, the estimated magnitude of the effect is very close to that found in the previous section, a $0.5 \%$ reduction in net debt issuances following the violation. This correspondence is comforting because it suggests that the sample selection concerns outlined earlier may be misplaced. That is, regardless of whether one looks at violations reported to the SEC or violations - reported or not - occurring in the Dealscan sample, the average financing response is quite similar. It is possible that both samples simply contain similar biases; however, we believe that this is a less plausible explanation for the consistency of results.

Column (2) adds a set of control variables often found in empirical studies of capital structure (e.g., Rajan and Zingales (1995) and Frank and Goyal (2005)). The estimated response of net debt issuing activity is basically unchanged in terms of magnitude and statistical significance. Finally, column (3) takes full advantage of the discontinuity design by including smooth functions of the underlying distance to the covenant threshold. We include both a linear and quadratic term for the current ratio and net worth distances interacted with an indicator variable identifying whether or not the loan contains a current ratio or net worth covenant, respectively. The results illustrate that the distance to the threshold contain relatively little information about security issuances, 
beyond that contained in the other control variables. None of the coefficients on these four measures are statistically distinguishable from zero. Additionally, the estimated treatment effect increases slightly to $0.6 \%$, while remaining statistically significant. In unreported analysis, we also examine the effect of including higher order terms. The results are qualitatively similar.

Because the discontinuity is the source of identifying information, we also estimate equation (4) on the subsample of firm-quarter observations that are close to the point of discontinuity - the "Discontinuity" sample. To remove some of the subjectivity associated with the definition of "close," Chava and Roberts (2006) choose a window width around the covenant threshold equal to 0.20 , which is based on the optimal window width for a nonparametric density estimation of a unimodal distribution. The key point is that the choice of window width, while subjective, is at least removed from any financing demands that the firm may have. Intuitively, this restriction aids in homogenizing the sample because a firm slightly above the covenant threshold should be relatively similar to that same firm slightly below the threshold but for the violation event.

The results are presented in Panel B of Table VIII. Following Angrist and Lavy (1999), we do not include the distance to the covenant violation in this specification because the range of the distance in the discontinuity sample is narrow enough that the indicator function is a valid instrument without these controls. Intuitively, by focusing on the subsample of observations close to the threshold, we effectively homogenize the violation and non-violation states, which are separated by only a small difference in the distance to the covenant threshold. Practically speaking, the collinearity between the indicator variable and smooth functions of the distance to default increases dramatically 
within a small interval because step functions are a basis for all smooth functions. Thus, disentangling the effects of the covenant violation captured by the indicator variable from those captured by the functions of the distance to the covenant threshold becomes infeasible.

The coefficient estimates for both specifications reveals virtually identical coefficient estimates for the net debt issuance response to those found in Panel A. The statistical significance of these estimates is weaker than that found in the full sample but this is more a result of the decline in degrees of freedom as opposed to economic significance. The number of observations decreases by over $60 \%$ as a result of focusing only on firms close to the covenant threshold. Thus, these results further emphasize that the event of the covenant violation is driving the financing response, as opposed to managerial preferences over capital structure.

\section{Additional Evidence from SEC filings}

The previous results provide large-sample evidence on the causal effect of the violation on security issuances by firms. In this section, we provide additional evidence from a random sample of covenant violators, for which we directly examine the 10-Q and $10-\mathrm{K}$ filings in the quarter of and after the covenant violation. Many firms provide detailed explanations of the outcome of the covenant violation, which provides unique insight into how creditors use their acceleration rights. The drawback of these data is that firms voluntarily choose the level of detail for their explanation to shareholders. The SEC does not provide strict guidelines for the reporting of covenant violations, other than requiring the firm to report the violation and its effect on the business if material. 
Therefore, the fact that a firm does not explicitly note that a creditor took some action does not imply that the creditor in fact took no action. In other words, our analysis of firm explanations provides a lower bound for the actual actions taken by creditors.

To give a sense of the data collection process, here is an example of an explanation from Insteel Industries, Inc. on their 2001 second quarter 10-Q filing:

At September 30, 2000, the Company was not in compliance with certain financial covenants of its senior secured credit facility, which constituted an event of default ... On January 12, 2001, the Company and its senior lenders agreed to an amendment to the credit agreement that modified these financial covenants, curing the event of default. Under the terms of this amendment, the maturity date of the credit facility was accelerated from January 31, 2005 to January 15, 2002 ...The Company also agreed to permanent reductions in the revolving credit facility from $\$ 60.0$ million to $\$ 50.0$ million at January 12,2001 ; to $\$ 45.0$ million at October 1, 2001, and to $\$ 40.0$ million at December 31, 2001.

These amendments have significantly increased the Company's interest expense as a result of: (1) scheduled increases in the applicable interest rate margins; (2) additional fees, a portion of which are calculated based upon the Company's stock price, payable to the lenders on certain dates and in increasing amounts based upon the timing of the completion of a refinancing of the credit facility, and (3) higher amortization expense related to capitalized financing.

For this particular company, as a direct result of the financial covenant violation, creditors reduced the credit facility, shortened the maturity of the loan, and raised the interest rate.

Table IX presents the results for a random sample of 100 covenant violators. In $31 \%$ of the cases, the creditors reduce the size of the credit facility in response to the covenant violation. Creditors reduce the size of the facility by cutting off access to the line of credit (5\%), terminating the credit agreement entirely $(8 \%)$, or reducing the size of the overall existing credit facility (18\%). Firms report that creditors increase the interest rate for $13 \%$ of the violations, and also collateralize the credit facility for $7 \%$ of 
violations. Finally, in $7 \%$ of the violations, the creditors force the borrower to issue convertible securities or equity.

While we caution against viewing these results in isolation, they provide complementary evidence to the large sample evidence presented in Sections IV and V. They provide additional insight into the manner in which creditors exercise their acceleration right, and suggest that creditors directly influence net security issuance decisions by forcing a reduction in the size of the outstanding credit facility.

\section{Conclusion}

This paper documents that the transfer of control accompanying covenant violations has significant consequences for corporate debt policy over and above any changes in manager's preferences for debt. Specifically, net debt issuances decline, on average, by 70 basis points in the quarter following a covenant violation. This sharp reduction in net debt issuance is persistent for two years following the violation, and leads to a reduction in leverage ratios by $3 \%$. These findings are robust to controls for the accounting variables on which covenants are written, as well as leverage rebalancing by firms. In fact, covenant violations greatly amplify reductions in net debt issuing activity accompanying leverage rebalancing. Thus, creditors take a significantly more conservative stance on optimal or target leverage, relative to that taken by managers.

In addition to identifying a role for control rights in determining financial policy, our results highlight an alternative perspective on capital structure that may shed light on several unresolved issues. For example, recent research (e.g., Molina (2005), Almeida and Philippon (2006), and Korteweg (2006)) has focused on alternative measures of 
bankruptcy costs to help explain debt conservatism (Graham (2000)). Similarly, numerous theoretical and empirical studies assume that firms' aversion to high leverage is driven by expected bankruptcy costs (e.g., Bradley, Jarrell and Kim (1984), Fischer, Heinkel, and Zechner (1989), Leland (1994), Hovakimian, Opler, and Titman (2001), Hovakimian (2006)). While a focus on improving the measurement of bankruptcy costs may yield more realistic patterns for capital structure, CFOs rank bankruptcy cost considerations seventh, in terms of their importance in debt financing decisions (Graham and Harvey (2001)).

Alternatively, CFOs rank maintenance of financial flexibility as the main reason for limiting debt financing. We believe that a consideration of creditor control rights over financial policy outside of bankruptcy may help explain debt conservatism, and may provide an explanation that is more in line with survey evidence. Our findings suggest that firms may appear ex post conservative because creditors use their acceleration rights to force reductions in debt against the will of managers. Our findings also suggest that firms may appear ex ante conservative given the expected costs associated with a loss of control over firm policy going forward. We look forward to future research pursuing these considerations. 


\section{References}

Aghion, Philippe and Bolton, Patrick, 1992, An incomplete contracts approach to financial contracting, Review of Economic Studies 59: 473-94

Almeida, Heitor and Thomas Philippon, 2006, The risk-adjusted cost of financial distress, Journal of Finance, forthcoming.

Altman, Edward I., 1968, Financial ratios, discriminant analysis, and the prediction of corporate bankruptcy, Journal of Finance 23: 589-609

Angrist, Joshua and Victor Lavy, 1999, Using Maimonides rule to estimate the effect of class size on scholastic achievement, Quarterly Journal of Economics 114: 533-575

Baker, Malcolm and Jeffrey Wurgler, 2002, The market timing theory of capital structure, Journal of Finance 57: 1-30

Beneish, Messod and Eric Press, 1993, Costs of technical violation of accounting-based debt covenants, The Accounting Review 68: 233-257

Beneish, Messod and Eric Press, 1995, The resolution of technical default, The Accounting Review 70: 337-353

Berger, Philip, Eli Ofek, and David Yermack , 1997, Journal of Finance 52, 1411-1438.

Bradley, Michael and Michael Roberts, 2003, The structure and pricing of corporate debt covenants, Working Paper, Duke University

Bradley, Michael, Gregg Jarrell, and Han Kim, 1984, On the existence of an optimal capital structure: Theory and evidence, Journal of Finance 39, 857-878.

Chava, Sudheer and Michael R. Roberts, 2006, Is Financial Contracting Costly? An Empirical Analysis of Debt Covenants and Corporate Investment, Working Paper, The Wharton School, University of Pennsylvania

Chen, Kevin C. W. and K. C. John Wei, 1993, Creditors' decisions to waive violations of accounting-based debt covenants, The Accounting Review 68: 218-232

Dewatripont, Mathias and Jean Tirole, 1994, A theory of debt and equity: diversity of securities and manager-shareholder congruence, Quarterly Journal of Economics 109: $1027-1054$

Dichev, Ilia D. and Douglas J. Skinner, 2002, Large sample evidence on the debt covenant hypothesis, Journal of Accounting Research 40: 1091 - 1123 
Fama, Eugene F. and Kenneth R. French, 2005, Financing decisions: Who issues stock?, forthcoming Journal of Financial Economics

Fischer, Edwin, Robert Heinkel, and Josef Zechner,1989, Dynamic capital structure choice: Theory and tests, Journal of Finance 44, 19-40.

Flannery, Mark and K Rangan, 2006, Partial adjustment toward target capital structures, Journal of Financial Economics 79: 469-506

Frank, Murray Z. and Vidhan K. Goyal, 2003, Testing the pecking order theory of capital structure, Journal of Financial Economics 67: 217-248

Frank, Murray Z. and Vidhan K. Goyal, 2005, Capital structure decisions: Which factors are reliably important?, Working Paper, University of British Columbia

Gale, Douglas and Martin Hellwig, 1985, Incentive-compatible debt contracts: the oneperiod problem, Review of Economic Studies 52, 647-663

Gopalakrishnan, V. and Mohinder Parkash, 1995, Borrower and lender perceptions of accounting information in corporate lending agreements, Accounting Horizons 9: 13-26

Graham, John R., 2000, How big are the tax benefits of debt, Journal of Finance 55, 1901-1941.

Graham, John R. and Campbell Harvey, 2001, The theory and practice of corporate finance: Evidence from the field, Journal of Financial Economics 60: 187-243

Hahn, Jinyong, Petra Todd and Wilbert van der Klaauw, 2001, Estimation of treatment effects with a quasi-experimental regression-discontinuity design, Econometrica 69: 201209

Hart, Oliver, 1995, Firms, Contracts, and Financial Structure, Oxford University Press, London.

Hart, Oliver and John Moore, 1988, Incomplete Contracts and Renegotiation, Econometrica 56, $755-785$.

Hart, Oliver and Moore, John, 1998, Default and renegotiation: A dynamic model of debt, Quarterly Journal of Economics 113: 1-42

Helwege, Jean and Nellie Liang, 1996, Is there a pecking order? Evidence from a panel of IPO firms, Journal of Financial Economics40: 429-458

Hovakimian, Armen, Tim Opler, and Sheridan Titman, 2001, Debt-equity choice, Journal of Financial and Quantitative Analysis 36: 1-24 
Hovakimian, Armen 2006, Are observed capital structures determined by equity market timing?, Journal of Financial and Quantitative Analysis 41: 221-243

Jensen, Michael C. and William H. Meckling, 1976, Theory of the firm: Managerial behavior, agency costs, and capital structure, Journal of Financial Economics 3:305-360

Kayhan, Ayla and Sheridan Titman, 2007, Firms histories and their capital structures, Journal of Financial Economics 83: 1-32

Korteweg, Arthur, 2006, The costs of financial distress across industries, Working paper, University of Chicago GSB.

Leary, Mark T. and Michael R. Roberts, 2005, Do firms rebalance their capital structures?, Journal of Finance 60: 2575 - 2619.

Leary, Mark T. and Michael R. Roberts, 2006, The pecking order, debt capacity, and information asymmetry, Working Paper, University of Pennsylvania

Leftwich, Richard, 1983, Accounting information in private markets: evidence from private lending agreements, The Accounting Review 58: 23-42

Leland, Hayne, 1994, Corporate debt value, bond covenants, and optimal capital structure, Journal of Finance 49, 1213-1252.

Lemmon, Michael, Michael R. Roberts, and Jaime Zender, 2006, Back to the beginning: Persistence and the cross-section of corporate capital structures

Liu, Laura, 2005, Do firms have target leverage ratios? Evidence from historical marketto-book and past returns, Working Paper, Honk Kong University of Science and Technology

Molina, Carlos, Are firms underlevered? An examination of the effect of leverage on default probabilities, Journal of Finance 60: 1427-1459

Myers, Stewart, 1977, Determinants of Corporate borrowing, Journal of Financial Economics 5: 147-175.

Myers, Stewart, 2003, Financing of corporations, Handbook of the Economics of Finance, ed. George Constantinides and Milton Harris, Elsevier, Amsterdam, The Netherlands.

Myers, Stewart and Nicholas Majluf, 1984, Corporate financing and investment decisions when firm have information investors do not have, Journal of Financial Economics 13: 187-221 
Nini, Greg, David Smith, and Amir Sufi, 2006, Creditor control rights and firm investment policy, Working Paper University of Chicago

Petersen, Mitchell A., 2006, Estimating standard errors in finance panel data sets: Comparing approaches, Working Paper, Northwestern University

Rajan, Raghuram G. and Luigi Zingales, 1995, What do we know about capital structure: Some evidence from international data, Journal of Finance 50: 1421-1460

Scott, J., 1976, A theory of optimal capital structure, The Bell Journal of Economics and Management Science 33-54

SEC, 2003, Interpretation: Commission guidance regarding management's discussion and analysis of financial condition and results of operations, available at: http://www.sec.gov/rules/interp/33-8350.htm

Smith, Clifford W. and Jerome B. Warner, 1979, On financial contracting: An analysis of bond covenants, Journal of Financial Economics 7: 117-161

Sufi, Amir, 2007, Bank lines of credit in corporate finance: An empirical analysis, Review of Financial Studies, forthcoming

Sweeney, Amy P., 1994, Debt covenant violations and managers' accounting responses, Journal of Accounting and Economics 17: 281-308

Townsend, Robert, 1979, Optimal contracts and competitive markets with costly state verification, Journal of Economic Theory 21: 265-293

Zwiebel, Jeffrey, 1996, Dynamic capital structure under managerial entrenchment, American Economic Review 86: 1197-1215 


\section{Appendix A: Variable Definitions}

This appendix details the variable construction for analysis of the Compustat sample.

Total Sales $=$ item 2

Total Assets $=$ item 44

Book Debt $=$ item $51+$ item 45

Net Equity Issuance $=($ item $84-$ item 93)/lagged item 44

Net Debt Issuance $=($ book debt - lagged book debt $) /$ lagged item 44

Market Value of Equity $=$ item $14 *$ item 61

Book Value of Equity $=$ item $44-($ item $54+$ annual item 10$)+$ item52

Tangible Assets = item 42

Net Worth $=$ item $44-$ item 54

Cash $=$ item 36

Net Working Capital $=$ item $40-$ item 49

EBITDA $=$ item 21

Cash Flow $=$ item $8+$ item 5

Net Income $=$ item 69

Interest Expense $=$ item 22 


\section{Table I \\ Financial Covenants}

This table presents the percentage of private credit agreements with various financial covenants. The sample includes 3,603 private credit agreements made to 1,894 firms.

\begin{tabular}{|c|c|c|c|}
\hline Type of Covenant & Fraction: & Type of Covenant & Fraction: \\
\hline Financial covenant & $96.5 \%$ & $\begin{array}{l}\text { Net worth/Tangible net worth } \\
\text { Net worth }\end{array}$ & $\begin{array}{l}45.2 \% \\
25.6 \%\end{array}$ \\
\hline Debt to cash flow & $57.5 \%$ & Tangible net worth & $19.0 \%$ \\
\hline Total debt to cash flow & $56.1 \%$ & Stockholders' equity & $0.8 \%$ \\
\hline \multirow[t]{2}{*}{ Senior debt to cash flow } & $8.6 \%$ & & \\
\hline & & Liquidity-based & $14.7 \%$ \\
\hline Debt to balance sheet item & $29.2 \%$ & Current ratio & $7.9 \%$ \\
\hline Debt to total capitalization & $19.8 \%$ & Quick ratio & $2.4 \%$ \\
\hline Debt to net worth & $6.9 \%$ & Working capital & $1.5 \%$ \\
\hline Debt to other balance sheet item & $3.4 \%$ & Other liquidity-based & $3.6 \%$ \\
\hline Debt in numerator covenants & $79.1 \%$ & Cash flow-based & $12.7 \%$ \\
\hline Coverage ratio & $74.3 \%$ & & \\
\hline Fixed charge coverage ratio & $38.1 \%$ & & \\
\hline Interest coverage ratio & $38.0 \%$ & & \\
\hline Debt service coverage ratio & $4.5 \%$ & & \\
\hline Other coverage ratio & $3.9 \%$ & & \\
\hline Debt or coverage ratio covenants & $89.2 \%$ & & \\
\hline
\end{tabular}




\section{Table II}

\section{Covenant Violations}

Panel A of this table presents the percentage of firms that report a financial covenant violation in $10-\mathrm{K}$ or 10-Q SEC filings at some point between 1996 and 2005. Panel B reports the 1-year probability of a financial covenant violation, and of default according to S\&P. S\&P 1-year cumulative default probabilities are equal-weighted averaged over ratings to get the probability for the broad rating class. The sample includes 6,381 firms and 135,736 firm-quarter observations.

PANEL A:

Fraction of firms that violate financial covenant

Totals

Total sample

Firms with average book leverage ratio greater than 0.05

By industry

Agriculture, minerals, construction

$28.5 \%$

Manufacturing

Transportation, communication, and utilities

Trade-wholesale

Trade-retail

Services

By size (book assets)

Less than $\$ 100 \mathrm{M}$

$\$ 100 \mathrm{M}$ to $\$ 250 \mathrm{M}$

$\$ 250 \mathrm{M}$ to $\$ 500 \mathrm{M}$

$\$ 500 \mathrm{M}$ to $\$ 1,000 \mathrm{M}$

$\$ 1,000 \mathrm{M}$ to $\$ 2,500 \mathrm{M}$

$\$ 2,500 \mathrm{M}$ to $\$ 5,000 \mathrm{M}$

Greater than $\$ 5,000 \mathrm{M}$

Borrower does not have credit rating

Borrower has credit rating
Percentage of firms

reporting violation

\section{PANEL B:}

1-year probabilities of default by credit rating

A or better

BBB

BB

$\mathrm{B}$

CCC or worse

Unrated
S\&P 1-year cumulative default

1-year probability of probability

\begin{tabular}{cc} 
covenant violation & probability \\
\hline $1.0 \%$ & $0.0 \%$ \\
$3.1 \%$ & $0.2 \%$ \\
$6.8 \%$ & $0.9 \%$ \\
$9.4 \%$ & $7.2 \%$ \\
$18.4 \%$ & $21.9 \%$ \\
$10.0 \%$ &
\end{tabular}


Table III

Summary Statistics

This table presents summary statistics for the unbalanced panel of 6,381 firms from 1996 through 2005 (135,736 firm-quarters). Net debt issuance and net equity issuance are scaled by lagged assets.

Capital structure variables

Net debt issuance (basis points)

Net equity issuance (basis points)

Covenant control variables

Book debt $_{\mathrm{t}} /$ assets $_{\mathrm{t}}$

Net worth $_{\mathrm{t}}$ assets $_{\mathrm{t}}$

Net working capital / $_{\mathrm{t}}$ assets $_{\mathrm{t}}$

Cash $_{\mathrm{t}} /$ assets $_{\mathrm{t}}$

EBITDA $_{t} /$ assets $_{t-1}$

Cash flow $_{\mathrm{t}} /$ assets $_{\mathrm{t}-1}$

Net income $_{\mathrm{t}} /$ assets $_{\mathrm{t}-1}$

Interest expense $\mathrm{t}_{\mathrm{t}} /$ assets $_{\mathrm{t}-1}$

Other control variables

Market to book ratio ${ }_{t}$

Tangible assets $\mathrm{t}_{\mathrm{t}}$ assets $_{\mathrm{t}}$

Ln(assets $)$

\begin{tabular}{ccc} 
Mean & Median & St. Dev. \\
\hline 50.5 & 0.0 & 400.8 \\
39.8 & 0.4 & 166.8
\end{tabular}

0.228

0.182

0.221

0.495

0.518

0.287

0.254

0.235

0.271

0.199

0.092

0.231

0.006

0.026

0.068

$-0.007$

0.017

0.074

$-0.022$

0.006

0.077

0.005

0.003

0.006

0.270

0.194

0.230

4.900

4.910

2.384 


\section{Table IV \\ Covenant Violations and Net Debt Issuance}

This table presents coefficient estimates of firm fixed effects regressions of net debt issuance on covenant violations and controls. The specifications reported in columns 2, 3, and 4 include lagged natural logarithm of total assets, the lagged tangible assets to total assets ratio, and the lagged market to book ratio as control variables. In addition, the specification in column 2 includes the 12 covenant control variables: the lagged book debt to assets ratio, the lagged net worth to assets ratio, the lagged cash to assets ratio, the lagged and current EBITDA to lagged assets ratio, the lagged and current cash flow to lagged assets ratio, the lagged and current net income to lagged asset ratio, and the lagged and current interest expense to lagged assets ratio. Specification 3 includes the covenant control variables in addition to 4 covenant control interaction variables: the lagged debt to assets ratio interacted with the lagged cash flow to lagged assets ratio, the lagged debt to assets ratio interacted with the lagged EBITDA to lagged assets ratio, the lagged debt to assets ratio interacted with the lagged net worth to assets ratio, and the lagged EBITDA to lagged assets ratio interacted with the lagged interest expense to lagged assets ratio. Specification 4 includes all covenant control variables and covenant control interaction variables, these variables squared and to the third power, and 5 quantile indicator variables for each of the controls. All specifications include quarter indicator variables and indicator variables for the fiscal quarter. Standard errors are clustered by firm.

Dependent variable: Net debt issuance ${ }_{t}$ assets $_{t-1}$ (basis points)

(1)

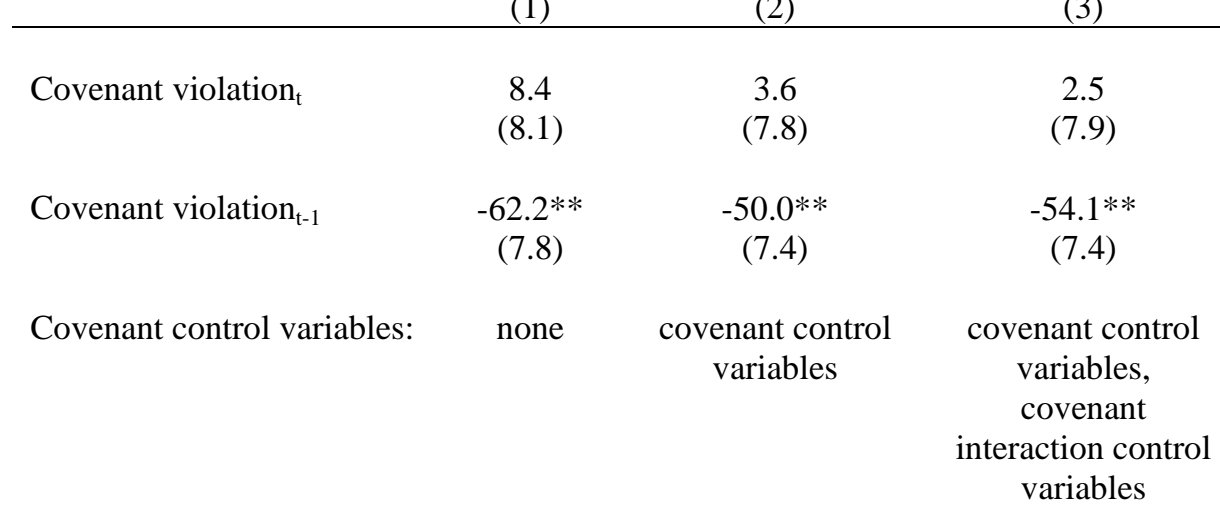

(4)

$-50.5^{* *}$

control variables, control variables squared, control variables to the third power, and quintile indicators for each control

\begin{tabular}{lcccc}
\hline Number of firm-quarters & 135,736 & 135,736 & 135,736 & 135,736 \\
Number of firms & 6,381 & 6,381 & 6,381 & 6,381 \\
$\mathrm{R}^{2}$ & 0.051 & 0.141 & 0.146 & 0.163 \\
\hline
\end{tabular}

*** statistically distinct from 0 at the 5 and 1 percent, respectively 


\section{Table V}

\section{Covenant Violations versus Leverage Rebalancing}

This table presents evidence on covenant violations and managerial leverage rebalancing. In Panel A, firmquarter observations at time $t$ are separated into quartiles based on the change in leverage from $t-2$ to $t-1$. In Panel B, firm-quarter observations at time $t$ are separated into quartiles based on the leverage ratio at $t-1$. For each quartile, the mean net debt issuance scaled by lagged assets at time $t$ are reported for firms that violate and do not violate a financial covenant at time $t-1$. The sample includes firms that have an average book leverage ratio of 0.05 or greater for the sample.

Panel A

Lagged change in leverage quartiles

Mean net debt issuance scaled by lagged assets (basis points) ${ }_{\mathrm{t}}$ No covenant violation $_{\mathrm{t}-1} \quad$ Covenant violation $_{\mathrm{t}-1}$

Quartile 1

Quartile 2

Quartile 3

51.1

$5.8^{* *}$

57.4

40.9

86.9

$-30.8^{* *}$

Quartile 4

80.9

$2.8^{* *}$

Panel B

Lagged leverage quartiles

Mean net debt issuance scaled by lagged assets (basis points) ${ }_{\mathrm{t}}$ No covenant violation $\mathrm{t}_{\mathrm{t}-1}$ Covenant violation $_{\mathrm{t}-1}$

Quartile 1

106.5

55.7

99.4

Quartile 2

39.5

Quartile 3

69.3

$14.5^{* *}$

$-15.9 * *$

Quartile 4

$-27.2^{* *}$

*** statistically distinct from "no covenant violation” at the 5 and 1 percent, respectively 


\section{Table VI \\ Covenant Violations and Leverage Rebalancing \\ A Regression Approach}

This table presents coefficient estimates from firm fixed effects regressions of net debt issuance on covenant violations and controls. In column (1), the sample is split into 4 quartiles based on the lagged change in the leverage ratio. In column (2), the sample is split into 4 quartiles based on the lagged leverage ratio. The sample includes firms that have an average book leverage ratio of 0.05 or greater for the sample. All specifications include quarter indicator variables and indicator variables for the fiscal quarter, in addition to lagged natural logarithm of total assets, the lagged tangible assets to assets ratio, and all covenant control variables in specification (3) reported in Table IV. Standard errors are clustered by firm.

Dependent variable: Net debt issuance $_{\mathrm{t}}$ assets $_{\mathrm{t}-1}$ (basis points)

(1)

(2)

Quartiles split by: Lagged change in leverage ratio

Lagged leverage ratio

\begin{tabular}{|c|c|c|}
\hline Quartile $2_{\mathrm{t}-1}$ & $\begin{array}{c}-18.2^{* *} \\
(4.1)\end{array}$ & $\begin{array}{l}-14.9 \\
(8.3)\end{array}$ \\
\hline Quartile $3_{\mathrm{t}-1}$ & $\begin{array}{c}-10.7^{*} \\
(4.8)\end{array}$ & $\begin{array}{c}-34.7^{* *} \\
(12.5)\end{array}$ \\
\hline Quartile $4_{\mathrm{t}-1}$ & $\begin{array}{c}-13.7^{*} \\
(5.3)\end{array}$ & $\begin{array}{c}-61.7^{* *} \\
(16.5)\end{array}$ \\
\hline Quartile $1_{\mathrm{t}-1} *$ Covenant violation $_{\mathrm{t}-1}$ & $\begin{array}{c}-42.9 * * \\
(15.0)\end{array}$ & $\begin{array}{c}5.5 \\
(18.4)\end{array}$ \\
\hline Quartile $2_{\mathrm{t}-1} *$ Covenant violation $_{\mathrm{t}-1}$ & $\begin{array}{c}-2.0 \\
(14.4)\end{array}$ & $\begin{array}{c}-36.6^{* *} \\
(14.2)\end{array}$ \\
\hline Quartile $3_{\mathrm{t}-1} *$ Covenant violation $_{\mathrm{t}-1}$ & $\begin{array}{c}-100.0^{* *} \\
(15.9)\end{array}$ & $\begin{array}{c}-51.5^{* *} \\
(14.2)\end{array}$ \\
\hline Quartile $4_{\mathrm{t}-1} *$ Covenant violation $_{\mathrm{t}-1}$ & $\begin{array}{c}-77.2^{* *} \\
(12.4)\end{array}$ & $\begin{array}{c}-109.8^{* *} \\
(14.3)\end{array}$ \\
\hline
\end{tabular}

\begin{tabular}{lcc}
\hline Number of firm-quarters & 104,383 & 104,383 \\
Number of firms & 4,765 & 4,765 \\
$\mathrm{R}^{2}$ & 0.150 & 0.150 \\
\hline
\end{tabular}

*,** statistically distinct from 0 at the 5 and 1 percent, respectively 


\section{Table VII}

\section{Long-Run Effect of Covenant Violations}

This table presents coefficient estimates from firm fixed effects regressions of net debt issuances (columns 1 through 4) and the leverage ratio (columns 5 and 6 ) on covenant violation indicator variables and control variables. Columns 2 through 4 contain identical control variables as columns 2 through 4 of Table IV, respectively. Column 6 contains the lagged logarithm of total assets, the lagged market to book ratio, the lagged tangible to assets ratio, the current and lagged EBITDA to lagged assets ratio, the current and lagged cash flow to lagged assets ratio, and the current and lagged net income to lagged assets ratio. All specifications include quarter indicator variables and indicator variables for the fiscal quarter. Standard errors are clustered by firm.

\begin{tabular}{|c|c|c|c|c|c|c|}
\hline \multirow{2}{*}{ Dependent variable: } & \multicolumn{4}{|c|}{ Net debt issuance ${ }_{t}$ assets $_{t-1}$ (basis points) } & \multicolumn{2}{|c|}{ Leverage ratio (basis points) } \\
\hline & $(1)$ & $(2)$ & $(3)$ & $(4)$ & $(5)$ & $(6)$ \\
\hline \multirow[t]{2}{*}{ Covenant violation $_{\mathrm{t}+2}$} & 13.4 & 21.9 & 22.0 & 17.6 & $162.8 * *$ & $143.4^{* *}$ \\
\hline & $(9.6)$ & $(9.1)$ & $(9.2)$ & $(9.0)$ & $(29.0)$ & $(28.6)$ \\
\hline \multirow[t]{2}{*}{ Covenant violation $_{\mathrm{t}+1}$} & 11.9 & 13.8 & 12.8 & 11.1 & $151.3^{* *}$ & $124.2^{* *}$ \\
\hline & $(9.3)$ & $(8.9)$ & $(8.9)$ & $(8.7)$ & $(26.7)$ & $(26.7)$ \\
\hline \multirow[t]{2}{*}{ Covenant violation $_{\mathrm{t}}$} & 15.2 & 10.1 & 8.8 & 9.1 & $233.9 * *$ & $173.0 * *$ \\
\hline & $(9.8)$ & $(9.3)$ & $(9.3)$ & $(9.2)$ & $(24.6)$ & $(24.5)$ \\
\hline \multirow[t]{2}{*}{ Covenant violation $_{\mathrm{t}-1}$} & $-32.8 * *$ & $-25.1 * *$ & $-28.7 * *$ & $-27.8 * *$ & $223.5^{* *}$ & $160.4^{* *}$ \\
\hline & $(9.6)$ & (9.1) & $(9.1)$ & $(9.0)$ & $(25.5)$ & $(25.4)$ \\
\hline \multirow{2}{*}{ Covenant violation $_{\mathrm{t}-2}$} & $-55.6 * *$ & $-46.2 * *$ & $-47.0 * *$ & $-46.6 * *$ & $123.8 * *$ & $101.0 * *$ \\
\hline & (9.3) & $(8.8)$ & $(8.8)$ & $(8.8)$ & $(24.0)$ & $(23.8)$ \\
\hline \multirow{2}{*}{ Covenant violation $_{\mathrm{t}-3}$} & $-30.9 * *$ & $-23.0 *$ & $-23.7^{*}$ & $-23.9 * *$ & $129.7^{* *}$ & $111.4^{* *}$ \\
\hline & (9.8) & $(9.3)$ & $(9.3)$ & $(9.1)$ & $(24.7)$ & $(24.3)$ \\
\hline \multirow[t]{2}{*}{ Covenant violation $_{\mathrm{t}-4}$} & $-27.1 * *$ & $-22.9 *$ & $-22.6^{*}$ & $-21.5^{*}$ & $96.0 * *$ & $79.7^{* *}$ \\
\hline & $(10.0)$ & $(9.5)$ & $(9.4)$ & $(9.5)$ & $(24.4)$ & $(23.8)$ \\
\hline \multirow[t]{2}{*}{ Covenant violation $_{\mathrm{t}-5}$} & $-47.8 * *$ & $-37.6 * *$ & $-37.6 * *$ & $-36.7 * *$ & $78.7 * *$ & $70.5^{* *}$ \\
\hline & (10.1) & $(9.5)$ & $(9.5)$ & $(9.5)$ & $(24.6)$ & $(24.2)$ \\
\hline \multirow[t]{2}{*}{ Covenant violation $_{\mathrm{t}-6}$} & $-26.5^{* *}$ & $-24.7 * *$ & $-24.8 * *$ & $-24.2 * *$ & 34.8 & 23.8 \\
\hline & (9.9) & $(9.4)$ & $(9.4)$ & $(9.3)$ & (23.3) & (22.9) \\
\hline \multirow[t]{2}{*}{ Covenant violation $_{\mathrm{t}-7}$} & -18.9 & $-21.2^{*}$ & $-19.7^{*}$ & -16.8 & 8.6 & 2.7 \\
\hline & $(9.9)$ & $(9.3)$ & $(9.3)$ & $(9.2)$ & $(24.7)$ & $(24.2)$ \\
\hline \multirow[t]{2}{*}{ Covenant violation $_{\mathrm{t}-8}$} & $-28.4 *$ & $-33.2 * *$ & $-32.8 * *$ & $-30.7 * *$ & 1.5 & 0.0 \\
\hline & $(10.1)$ & $(9.5)$ & $(9.5)$ & $(9.5)$ & $(29.2)$ & $(28.7)$ \\
\hline Number of firm-quarters & 81,673 & 81,673 & 81,673 & 81,673 & 81,673 & 81,673 \\
\hline Number of firms & 5,311 & 5,311 & 5,311 & 5,311 & 5,311 & 5,311 \\
\hline $\mathrm{R}^{2}$ & 0.054 & 0.145 & 0.150 & 0.166 & 0.790 & 0.798 \\
\hline
\end{tabular}

*,** statistically distinct from 0 at the 5 and 1 percent, respectively 


\section{Table VIII \\ Covenant Violations and Net Debt Issuance \\ Regression Discontinuity Sample}

This table presents coefficient estimates of firm fixed effects regressions of net debt issuance on covenant violations and controls. The sample consists of all firm-quarter observations in which a covenant restricting the current ratio or net worth of the firm is imposed by a private loan found in Dealscan during 1994-2005. Panel A presents the results for the entire Dealscan sample. Panel B presents the results for the discontinuity Dealscan sample, defined as those firm-quarter observations in which the absolute value of the relative distance to the covenant threshold is less than 0.20. All specifications include quarter indicator variables. Standard errors are clustered by firm.

\section{PANEL A: ENTIRE DEALSCAN SAMPLE}

Dependent variable: Net debt issuance tassets $_{\mathrm{t}-1}$ (basis points)

(1)

Covenant violation $_{\mathrm{t}-1} \quad-47.1$

Market to book $\mathrm{t}_{\mathrm{t}-1}$

Profitability $_{\mathrm{t}-1}$
(2)

$-53.7^{*}$

(23.4)

$56.4 * *$

$-835.2$

Firm size $_{\mathrm{t}-1}$

Altman's Z-Score $_{\mathrm{t}-1}$

Tangibility ${ }_{\mathrm{t}-1}$

Industry Median Leverage ${ }_{t-1}$

Default Distance (CR) $)_{\mathrm{t}-1}$

(Default Distance $\left.(\mathrm{CR})_{\mathrm{t}-1}\right)^{2}$

Default Distance (CR) $\mathrm{t}_{\mathrm{t}-1}$
$-130.6 * *$ $(-47.7)$

$65.3 * *$

$675.4^{* *}$

(270.4)

$-69.4$

(174.2)
(3)

$-59.8 *$

$59.3^{* *}$

$-846.8$

(438.2)

$-150.7^{* *}$

$72.6^{* *}$

$634.7^{* *}$

(270.0)

$-0.7$

(174.3)

$-37.2$

(34.4)

$-7.2$

(7.6)

0.1

(0.0)

\begin{tabular}{lr} 
(Default Distance $\left.(\mathrm{CR})_{\mathrm{t}-1}\right)^{2}$ & 0.0 \\
\hline
\end{tabular}

(0.0)

4,609

\begin{tabular}{lccc}
\hline Number of firm-quarters & 4,609 & 4,609 & 4,609 \\
$\mathrm{R}^{2}$ & 0.125 & 0.137 & 0.139 \\
\hline
\end{tabular}

*,** statistically distinct from 0 at the 5 and 1 percent, respectively 


\section{Table VIII}

\section{Covenant Violations and Net Debt Issuance}

Regression Discontinuity Sample

\section{PANEL B: DISCONTINUITY DEALSCAN SAMPLE}

Dependent variable: Net debt issuance ${ }_{t} /$ assets $_{\mathrm{t}-1}$ (basis points)

(1)

$-62.0$

(35.6)
(2)

$-58.3$

(35.4)

Market to book $\mathrm{t}_{-1}$

Profitability $_{\mathrm{t}-1}$ 255.9

Firm size $_{\mathrm{t}-1}$ $-385.0 * *$

Altman's Z-Score ${ }_{t-1}$ 181.0

Tangibility $\mathrm{t}-1$ 777.1 (546.3)

Industry Median Leverage $\mathrm{t}_{\mathrm{t}-1}$

\begin{tabular}{lcc}
\hline Number of firm-quarters & 4,609 & 4,609 \\
$\mathrm{R}^{2}$ & 0.283 & 0.307 \\
\hline$*, * *$ statistically distinct from 0 at the 5 and 1 percent, respectively &
\end{tabular}

*,** statistically distinct from 0 at the 5 and 1 percent, respectively 


\section{Table IX}

\section{The Response of Creditors to Covenant Violations}

This table presents evidence from SEC 10-K and 10-Q filings on how creditors respond to financial covenant violations. The data reported in this table are for a random sample of 100 covenant violators for whom we examine the filings in the quarter of and after the violation.

As a direct result of violation, fraction of borrowers that report:

Fraction

Reduction in size of credit facility $\quad 0.31$

Borrower loses access to revolver/line of credit $\quad 0.05$

$\begin{array}{ll}\text { Existing credit agreement terminated } & 0.08\end{array}$

$\begin{array}{ll}\text { Existing credit agreement reduced in size } & 0.18\end{array}$

$\begin{array}{ll}\text { Interest rate increased } & 0.13\end{array}$

$\begin{array}{ll}\text { Borrower forced to issue warrants/equity } & 0.07\end{array}$

$\begin{array}{ll}\text { Additional collateral required } & 0.07\end{array}$ 
Figure 1

Net Debt Issuance Before and After a Covenant Violation, Full Sample

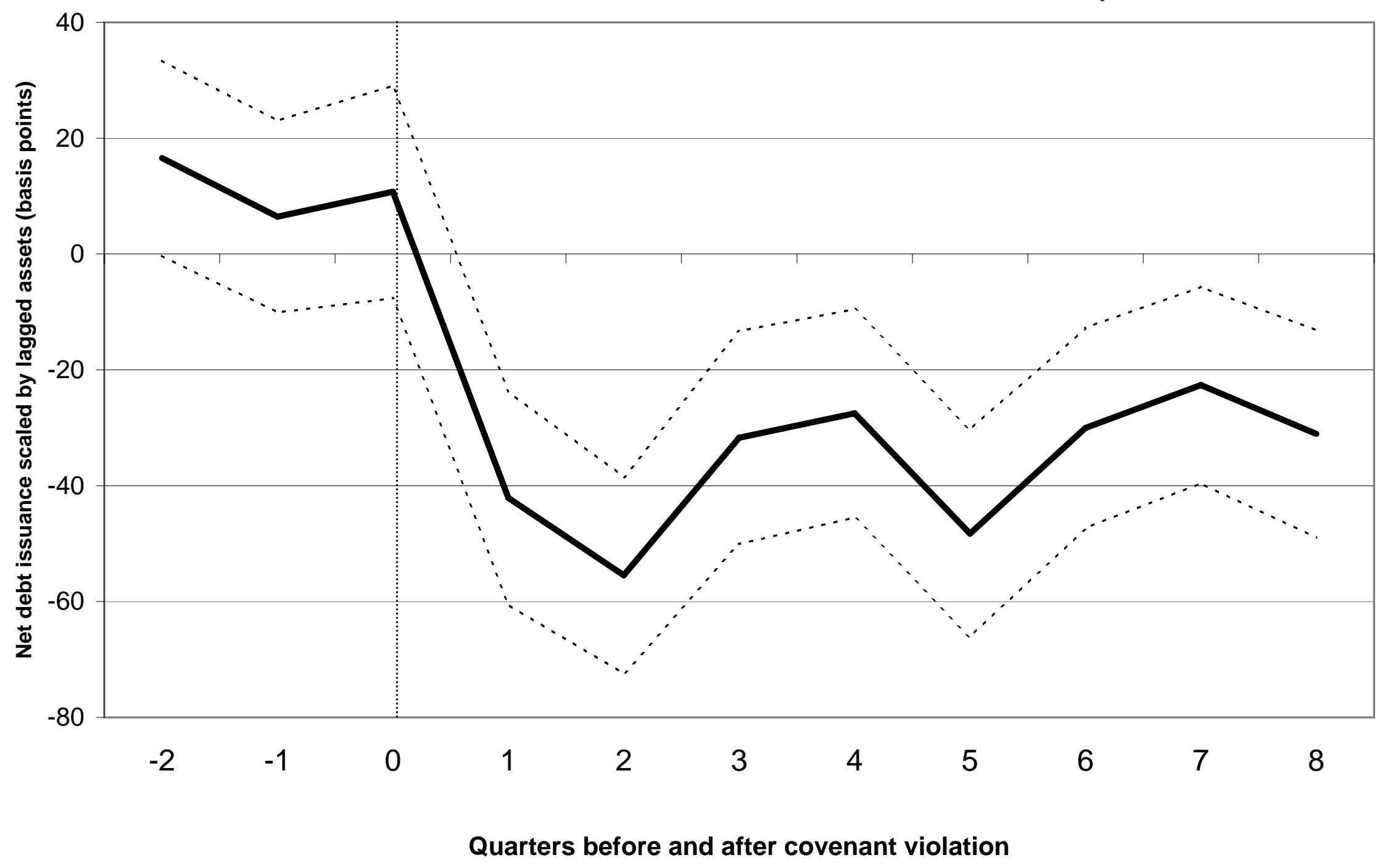


Figure 2

Net Equity Issuance Before and After a Covenant Violation, Full Sample

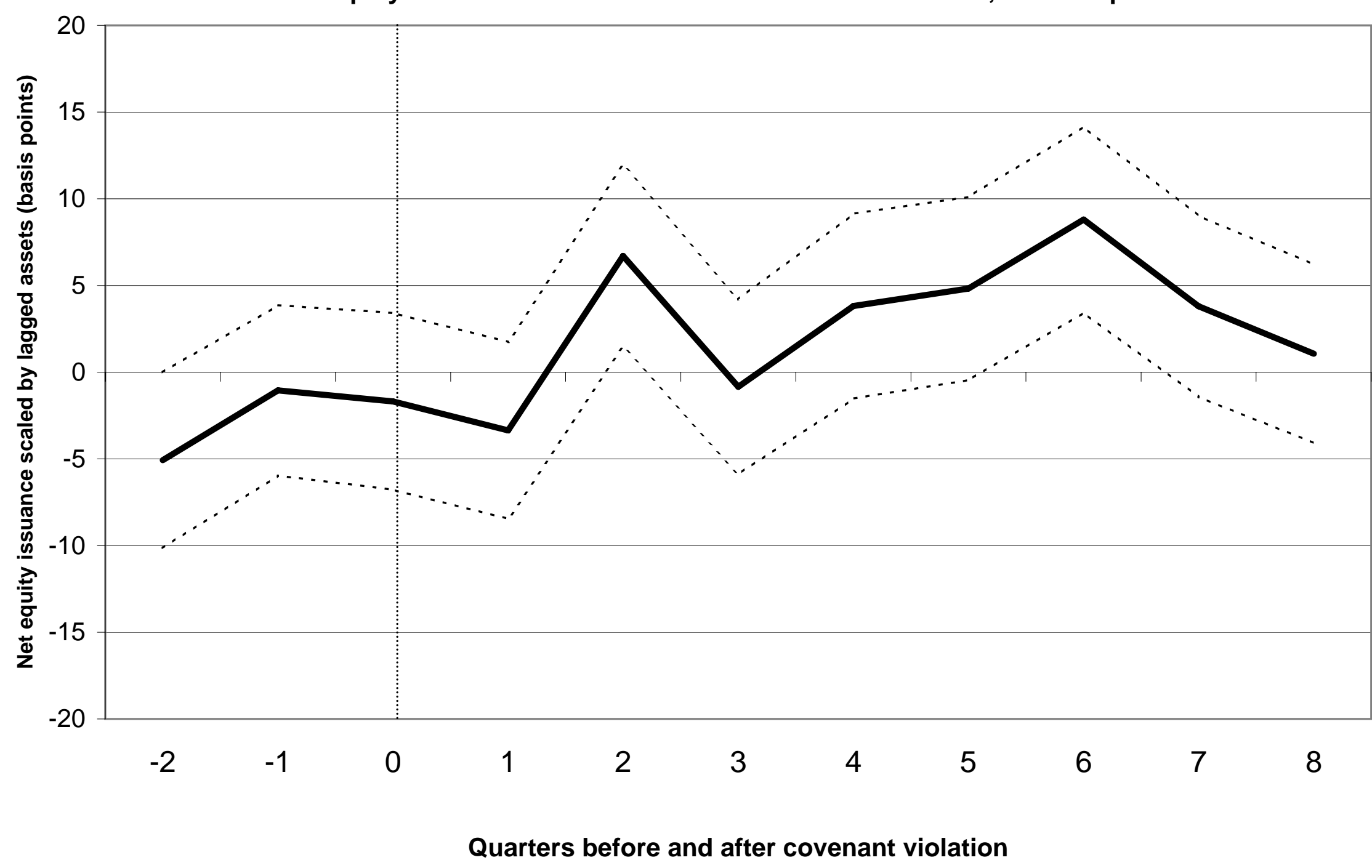


Figure 3

Book Leverage Ratio Before and After a Covenant Volation, Full Sample

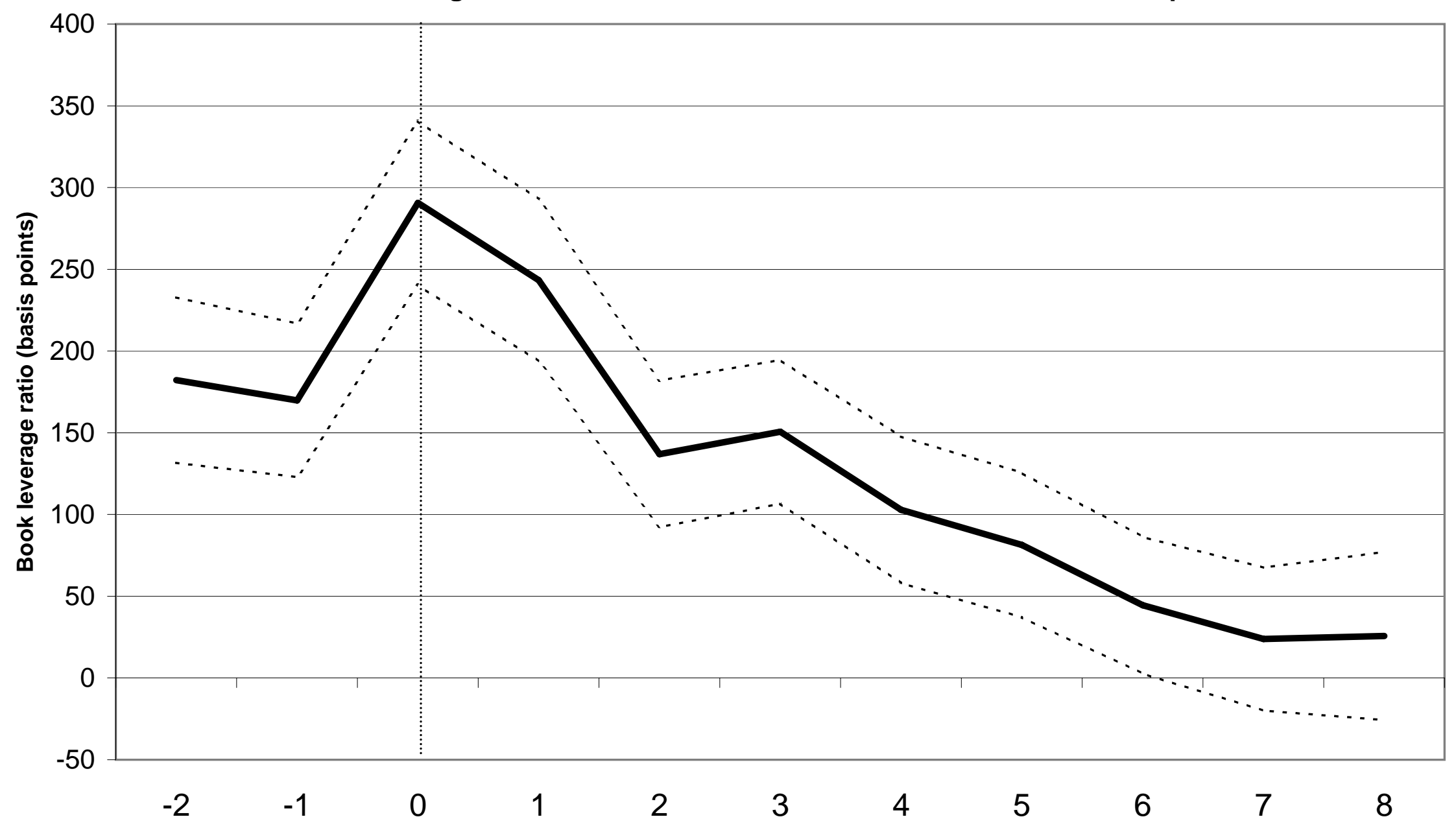

Quarters before and after covenant violation 
Figure 4

Net Debt Issuance before and after Covenant Violation, Regression Discontinuity Sample

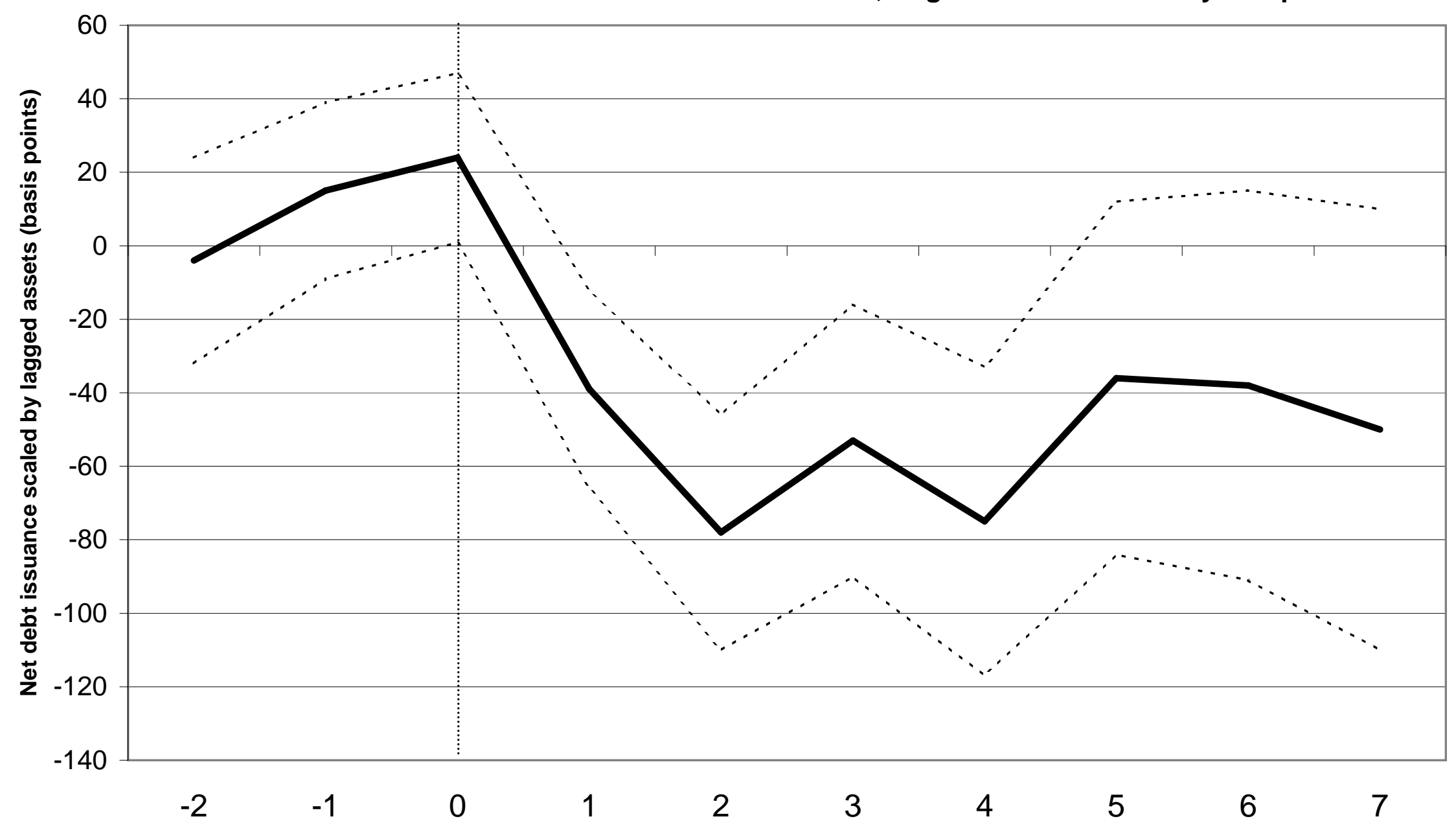

Quarters before and after covenant violation 